\title{
THE ABILITY OF FRUIT AND VEGETABLE ENZYME SYSTEM TO HYDROLYSE ESTER BONDS ${ }^{1}$
}

\author{
AgNiESZKA MironowicZ, Bogdan JAROSZ, ANTONI SIEWIŃSKI ${ }^{2}$ \\ Deptartment of Fundamental Chemistry, Agricultural University of Wrocław, \\ ul. Norwida 25, 50-375 Wrocław, Poland
}

(Received: May 30, 1995. Accepted: July 10, 1995)

\begin{abstract}
The pulp of potato tubers (Solanum tuberosum), topinambur (Helianthus tuberosus) and apples (Malus silvestris) can hydrolyse totally, or almost totally, ester bonds in phenyl, $\alpha$ - and $\beta$-naphthyl, benzyl and cinnamyl acetates. In methyl 4-acetoxy-3-metoxybenzoate and methyl 2,5-diacetoxybenzoate as well as testosterone propionate and 16,17-acetonide of 21-acetoxy-6-fluoro-16 $\alpha, 17 \beta, 21$-trihydroxy-4-pregnen-3,20-dione, the hydrolysis is selective towards the substrate and the bioreagent. In contrast, ethyl benzoate and cinnamate are resistant to hydrolysis.
\end{abstract}

KEY WORDS: Malus silvestris, Solanum tuberosum, Helianthus tuberosus, hydrolysis of esters, shikimic acid derivatives, fruit pulp, biotransformation.

\section{INTRODUCTION}

The role of higher plants used in biotransformations as reagents helpful in carrying out various chemical reactions is steadily increasing (Berlin, 1984, 1988). Recent technologies favour the use of tissue cultures in biotransformations (Mironowicz et al., 1987; Yoshinobu Naoshima and Yoshihiko Akakabe, 1991), but the use of whole plants for this purpose has been reported by very few authors, who made attempts to carry out steroid biotransformations using the pulp of potato tuber or different kinds of fruit (Nguyen Gia Chan and Procházka, 1972).

In our laboratory, for the first time we experimented on duckweed (Spirodela punctata, former name: oligorrhiza) which was used as a whole, intact plant to carry out biotransformations of isoprenoids (Tłomak et al., 1986) and shikimic acid derivatives (Pawłowicz and Siewiński, 1987, Pawłowicz, 1988). Each fragment of the substrate structure contained an ester bond in various geometrical arrangements. The hydrolysis of the ester bond was found to be selective and substratedependent. The most sensitive were phenyl-, and aromatic acetates, whereas esters of aromatic acids with/and aliphatic alcohols proved to be resistant to the bioreagent (duckweed). A similar substrate-dependent selectivity was observed when whole intact plants of Nephrolepsis exaltata and Cyrtomium falcatum, or suspension cultures of Helianthus tuberosus, Daucus carota and Petunia hybrida (Mironowicz et al., 1994), or orchid tissue cultures of Cymbidium 'Saint Pierre'

\footnotetext{
'Part 38 of the Series „Biotransformations”. Part 37: see Jarosz and Siewiński 1995

${ }^{2}$ Reprint requests to A. Siewiński
}

and Dendrobium phalaenopsis (Mironowicz et al., 1993) were used as bioreagents in the transformations of the same groups of esters. The substrate-dependent selectivity of the esters belonging to shikimic acid derivatives was confirmed in consecutive studies on both whole, intact plants and tissue or cell cultures of different genera of higher plants. These results encourage us to continue our research using other plants as bioreagents. In the biotransformations described in this paper we used fruit and vegetable pulp as bioreagents and the substrates mentioned above.

\section{MATERIAL AND METHODS}

\section{Bioreagents.}

Apples (Malus silvestris) of Gloucester and Golden varieties were received from the Institute of Pomology, Wróblowice near Wrocław. The harvest-time of these two varieties is the second decade of October. The Golden variety is suitable for consumption from November to April, Gloucester from December to May. The transformations were carried out at that time. Potato tubers (Solanum tuberosum) of Saturna variety were obtained from the Company "Flessner Polski" in Oława (Wrocław voivodeship). Topinambur (Helianhus tuberosus) was from the Experiment Station of Agricultural Academy, Wrocław, Poland. All transformations were carried out at the time when the fruit and vegetables were suitable for consumption.

\section{Substrates.}

Esters used for biotransformations were obtained from: P.O.Ch. (Gliwice, Poland), Aldrich and Fluka. 


\section{Transformation.}

A healthy, undamaged fruit or tuber was washed in warm water with soap and next rinsed with water. The core and stalks of the apples were removed. Comminution was performed in an electric mixer for 2 min and the obtained pulp was placed in Erlenmayer flasks with $50 \mathrm{~cm}^{3}$ of phosphate buffer, at $\mathrm{pH}$ similar to that of natural fruit juice ( $\mathrm{pH}$ of apple juice $=$ $4.5, \mathrm{pH}$ of potato tubers and topinambur $=5.9$ ). The biomass used in one trial was $20 \mathrm{~cm}^{3}$, i.e. $1.7 \mathrm{~g}$ of apple pulp, $3.5 \mathrm{~g}$ of potato and $4.0 \mathrm{~g}$ of topinambur pulp in conversion to dry mass (after drying at $105^{\circ} \mathrm{C}$ for $12 \mathrm{~h}$ ).

20-30 mg of substrate dissolved in $0.5 \mathrm{~cm}^{3}$ of acetone was added to the suspension and shaken for $48 \mathrm{~h}$. The products were extracted with chloroform. Their structure was identified by thin-layer and gas chromatography (Hewlett-Packard 5890 , FID, carrier gas - hydrogen). Original compounds were used for comparison. The spectral method (IR: Spectrophotometer Specord M-80) was used in special cases, after preparative chromatography $\left(\mathrm{SiO}_{2}, 0.2-0.05 \mathrm{~mm}\right.$, Merck).

Gas chromatography was performed using a Hewlett Packard 5890, equipped with HP-5 colum (5\% Phenyl Methyl Silicone); $30 \mathrm{~m}$, inside diam. $0.53 \mathrm{~mm}$, film thickness $0.88 \mu \mathrm{m}$.

The experiments were performed in several replications for confirmation of the results and for isolation of the adequate quantities of the products for further studies.

Additional experiments were performed to find out how the material consisting of fruit and vegetables (selected for biotransformations) can be affected by storage. It was found that the ability of Saturna potatoes to transform menthyl acetate was reduced when storage was prolonged. The decrease in the degree of hydrolysis was significant; from $63 \%$ in November and $56 \%$ in May to $26 \%$ in June.

\section{RESULTS AND DISCUSSION}

The aim of our investigation was to find whether apples and vegetables could be used as reagents in biotransformations of some chemical compounds. The material taken for the studies consisted of potato pulp (Solanum tuberosum), topinambur (Helianthus tuberosus) and two apple varieties (Malus silvestris). Originally, the fruit pulp was sterile. The experiment was performed for $48 \mathrm{~h}$. It was found that under the experimental conditions some bacterial cells occurred, however, they did not affect the degree of hydrolysis.

Our attention was primarily focused on substrate-dependent selectivity of hydrolysis (Pawłowicz and Siewiński, 1987; Mironowicz et al., 1993, 1994) of ester bonds of shikimic acid derivatives by cultures of selected bioreagents.

In the present study, we used 11 esters, structurally close to shikimic acid, the main precursor of aromatic amino acids. The results of transformations of these compounds in the cultures of higher plants can provide important information for chemotaxonomy of investigated plants. Phenyl acetate (1), $\alpha$ and $\beta$-naphthyl acetates ( 2 and 3 ), benzyl acetate (4), cinnamyl acetate (5), methyl 4-acetoxy-3-methoxybenzoate (6), methyl 2,5-diacetoxibenzoate (7) ethyl benzoate (8), and ethyl cinnamate (9). Besides, testosterone acetate (10) and 16,17acetonide of 21 -acetoxy- $6 \alpha$-fluoro- $16 \alpha, 17 \alpha, 21$-trihydroxy-4pregnen-3,20-dione (11) were used for the transformations. (Fig. 1).

Usually, 48-hour transformation followed by extraction with chloroform and spectral and/or chromatographycal identification yielded the products of the hydrolysis of 1 to 7 acetates (group of shikimic acid derivatives) and testosterone acetate (10). Selectivity of hydrolysis of the ester bond, both substrate- and bioreagent-dependent was clearly seen in aromatic ( 8 and 9 ) and steroid (10 and 11) substrates. The yield of the reaction was in each case different.

The structure of aromatic acetate fragment undergoing the hydrolysis described above is as follows:

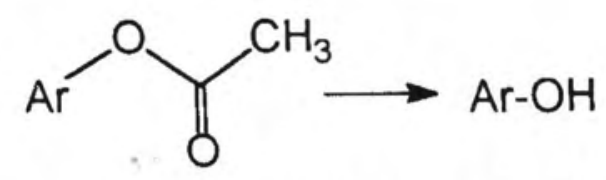

where $\mathrm{Ar}$ is a phenyl, naphthyl or benzyl group in substrates 1-7.

The structure of the fragment of esters resistant to hydrolysis, or undergoing hydrolysis when some of the four bioreagents are used, is as follows:

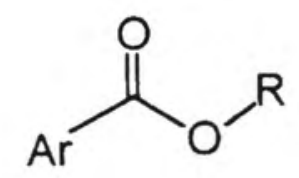

where $\mathrm{Ar}$ is a fragment with aromatic ring, and $\mathrm{R}$ is an ethyl group in substrates 8 and 9 or methyl group in substrates 6 and 7.

The first four columns of Table 1 show the data of 48-hour hydrolysis of 11 esters in the medium consisting of two apple varieties, potato or topinambur tubers. For comparison, five other columns have been added to Table 1 to show the data obtained in earlier studies, where suspension cultures of topinambur (Helianthus tuberosus), carrots (Daucus carota) and petunia (Petunia hybrida) (Mironowicz et al. 1993), whole intact duckweed (Spirodela punctata) (Pawłowicz et al., 1987) and fern plants (Nephrolepsis cordifolia) (Mironowicz et al., 1994) were used for two-week biotransformations of the same aromatic esters.

The activity of bioreagents shown in Table 1 proves that the degree of hydrolysis is much higher when whole, intact plants are used, as compared to suspension cultures. The comparison of the same plant, e.g. topinambur used for the biotransformations in intact form and then as suspension culture is particularly interesting, as it shows a significant difference in its ability to hydrolyse esters. In each case, the ability of the whole plant to hydrolyse esters was much higher than that of suspension culture (esters 1, 4, 5, 6, 7).

Generally, the data obtained in the present study confirm our earlier observations that phenol acetates and aromatic alcohol acetates are sensitive to the bioreagents; e.g. they are able to hydrolyse acetates $1,2,3$ to a high degree, or even completely.

These simple esters were also used in our earlier experiments on orchid tissue cultures (Cymbidium 'Saint Pierre' and Dendrobium phalaenopsis) (Mironowicz et al., 1993). All the substrates were hydrolysed in the environment of orchid tissue cultures, but the degree of hydrolysis varied depending on substrates and bioreagents. This information had been used in further studies on ester hydrolysis performed with other bioreagents. In contrast, esters in which the carbonyl group is on aromatic side are resistant to hydrolysis in the same environment. Potato is the only bioreagent which is able to hydrolyse them, but only to a slight degree (substrates 8 and 9).

Alcohols, as the products of hydrolysis proved to be stable under conditions of the transformation described. 


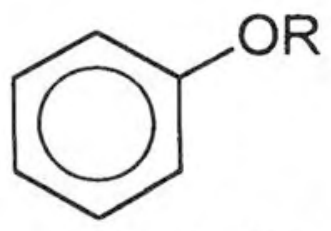

1: $\mathrm{R}=\mathrm{AC}$

1a: $\mathrm{R}=\mathrm{H}$

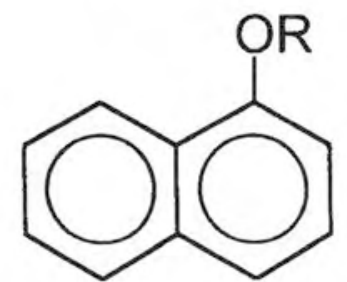

$2: R=A C$

2a: $\mathrm{R}=\mathrm{H}$

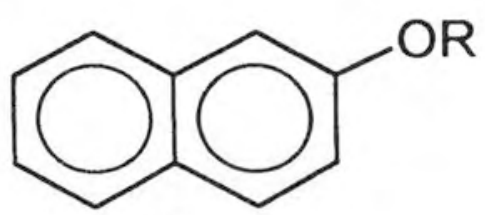

3: $\mathrm{R}=\mathrm{AC}$

3a: $\mathrm{R}=\mathrm{H}$

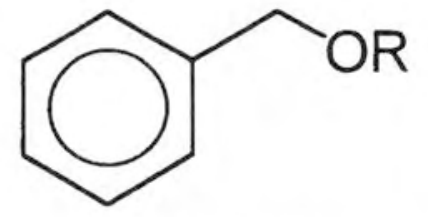

4: $\mathrm{R}=\mathrm{AC}$

4a: $R=H$

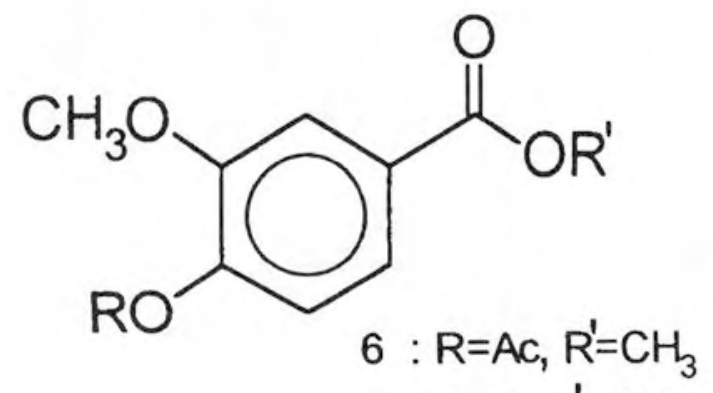

6a: $\mathrm{R}=\mathrm{H}, \mathrm{R}^{\prime}=\mathrm{CH}_{3}$

6b: $R=R^{\prime}=H$

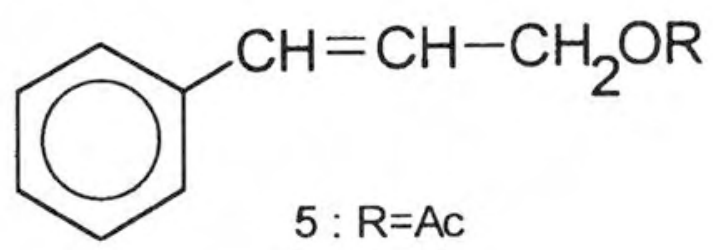

5a: $\mathrm{R}=\mathrm{H}$
$8: R=E t$

8a: $\mathrm{R}=\mathrm{H}$

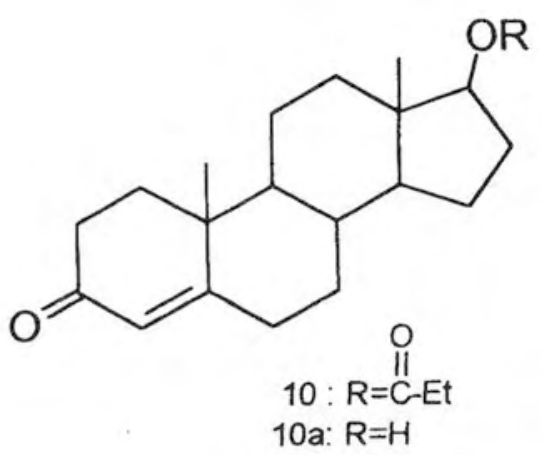

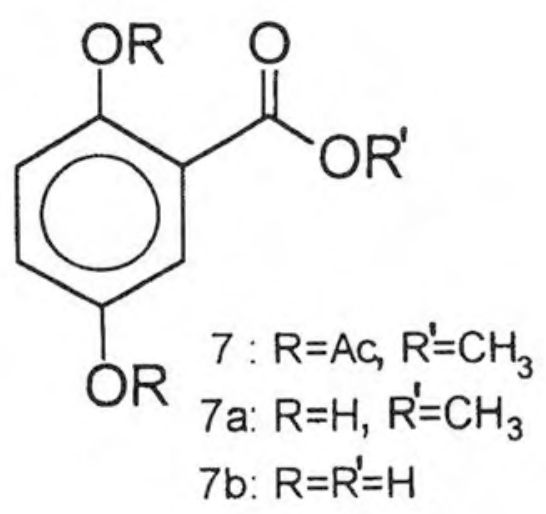


TABLE 1. Degree of ester hydrolysis to alcohols and/or acids using apple and vegetable pulp (columns 1-4), tissue cultures (column 5), whole intact higher plants (columns 6-7), or cell suspensions (column 8-9).

\begin{tabular}{|c|c|c|c|c|c|c|c|c|c|c|}
\hline \multicolumn{2}{|c|}{ Number of: } & \multicolumn{9}{|c|}{ Degree of hydrolysis of esters to alcohols and/or acids [\%] } \\
\hline \multirow[t]{3}{*}{ substrate } & \multirow[t]{3}{*}{ product } & \multicolumn{2}{|c|}{ Apples } & \multirow[t]{2}{*}{ Potato } & \multicolumn{2}{|c|}{ Topinambur } & \multirow{2}{*}{$\begin{array}{c}\text { S. } \\
\text { punct. } * *\end{array}$} & \multirow{2}{*}{$\begin{array}{l}\text { N. } \\
\text { cord.* }\end{array}$} & \multirow{2}{*}{$\begin{array}{l}\text { D. } \\
\text { car.* }\end{array}$} & \multirow{2}{*}{$\begin{array}{c}\text { P. } \\
\text { hybr.* }\end{array}$} \\
\hline & & 'Gloster' & 'Golden' & & $\begin{array}{c}\text { grated } \\
\text { bulb }\end{array}$ & $\begin{array}{l}\text { susp. } \\
\text { cult*. }\end{array}$ & & & & \\
\hline & & 1 & 2 & 3 & 4 & 5 & 6 & 7 & 8 & 9 \\
\hline 1 & la & 100 & 100 & 100 & 100 & 65 & 100 & 100 & 8 & 8 \\
\hline 2 & $2 \mathrm{a}$ & 100 & 100 & 99 & 91 & - & - & - & - & - \\
\hline 3 & $3 a$ & 100 & 100 & 3 & 30 & - & - & - & - & - \\
\hline 4 & $4 a$ & 100 & 100 & 100 & 88 & 13 & 100 & 100 & 50 & 8 \\
\hline 5 & $5 a$ & 100 & 100 & 100 & 65 & 5 & 57 & 93 & 6 & 6 \\
\hline \multirow[t]{2}{*}{6} & $6 a$ & 60 & 50 & 98 & 100 & $49^{\dagger}$ & 100 & \multirow[t]{2}{*}{-} & 100 & \multirow[t]{2}{*}{-} \\
\hline & $6 \mathrm{~b}$ & 40 & 50 & 0 & 0 & 0 & 0 & & 0 & \\
\hline \multirow[t]{2}{*}{7} & $7 \mathrm{a}$ & 90 & 0 & 90 & 100 & 54 & 100 & \multirow[t]{2}{*}{-} & 64 & 73 \\
\hline & $7 b$ & 10 & 100 & 0 & 0 & 0 & 0 & & 0 & 0 \\
\hline 8 & $8 \mathrm{a}$ & 0 & 0 & 10 & 0 & $0^{\dagger}$ & $0^{\frac{1}{*}}$ & - & $0^{\dagger}$ & $0^{\dagger}$ \\
\hline 9 & $9 a$ & 0 & 0 & 20 & 0 & $0^{\dagger}$ & $0^{\ddagger}$ & - & $0^{\dagger}$ & $0^{\dagger}$ \\
\hline 10 & $10 \mathrm{a}$ & 61 & 34 & 2 & 2 & - & 6 & - & - & - \\
\hline 11 & $11 \mathrm{a}$ & 0 & 0 & 40 & 0 & - & - & - & - & - \\
\hline
\end{tabular}

- transformation not investigated

* results from Mironowicz et al. 1994

** results from Pawłowicz et al. 1987

$\dagger$ unpublished data obtained in biotransformations carried out by the method according to Mironowicz et al. 1994

$\doteqdot$ data for methyl ester

The same products (potato tubers and topinambur) were used for transformations of the chemicals inhibiting potato sprouting during storage, i.e. indole-3-acetic acid and 1-nonanol. Neither potato tubers nor topinambur caused decomposition of these compounds.

\section{ACKNOWLEDGEMENTS}

The authors wish to thank The Polish Committee for Scientific Research (KBN), grant 6606792 03, for finantial support.

\section{LITERATURE CITED}

BERLIN J., 1984. Plant cultures - a future source of natural products? Endeavour, New Series 8: 5-8.

BERLIN J., 1988. Biotechnology in Agriculture and Foresty, vol. 4, Medicinal and Aromatic Plants I, ed. by Y.P.S. Baiaj, Springer Verlag Berlin, Heidelberg, Formation of Secondary Metabolites in Cultured Plants and Its Impact on Pharmacy.

JAROSZ B., SIEWIŃSKI A., 1995, Enantiospecific reduction of prochiral ketones of aromatic type to optically active alcohols in a $\mathrm{Ni}$ grospora oryzae culture, Appl. Microbiol. Biotechnol., in press.
MIRONOWICZ A., KUKUŁCZANKA K., KRASIŃSKI K., SIEWIŃSKI A., 1987. Transformation of isoprenoids by orchids in tissue cultures, Phytochemistry, 26: 1959-1960.

MIRONOWICZ A., KUKUŁCZANKA K., SIEWŃISKI A., 1993. Substrate specific hydrolysis of aromatic and aromatic-aliphatic esters in orchid tissue cultures, Acta Soc. Bot. Pol., 62: 21-23.

MIRONOWICZ A., KROMER K., PAWŁOWICZ P., SIEWIŃSKI A., 1994. Abilities of some higher plants to hydrolyze the acetates of phenols and aromatic-aliphatic alcohols, Acta Soc. Bot. Pol., 63: 43-48.

NGUYEN GIA CHAN, PROHÁZKA Ž., 1972. Saponification of esters of steroid acids and some other esters by potato tuber slices and some other plant tissues, Call. Czech. Chem. Commun., 38: 227-234.

PAWŁOWICZ P., SIEWIŃSKI A., 1987. Enantioselective hydrolysis of esters and the oxidation of aromatic-aliphatic alcohols obtained therefrom by Spirodela oligorrhiza, Phytochemistry, 26: 10011004

PAWŁOWICZ P., PIĄTKOWSKI K., SIEWIŃSKI A., 1988. Enantiospecific hydrolysis of acetates of racemic monoterpenic alcohols by Spirodela oligorrhiza, Phytochemistry 27: 2809-2811.

PAWŁOWICZ P., WAWRZEŇCZYK CZ., SIEWIŃSKI A., 1992. Uncommon type of hydroxylation of 3-alkenylsubstitued derivatives of citronellol and cytronellic acid by Spirodela punctata, Phytochemistry, 31: 2355-2357. 
TŁOMAK E., PAWŁOWICZ P., CZERWIŃSKI W., SIEWIŃSKI A., 1986. Transformation of androstane derivatives by Spirodela oligorrhiza, Phytochemistry 25: 61-64.
YOSHINOBU NAOSHIMA, YOSHIHIKO AKAKABE, 1991. Biotransformation of aromatic ketones with cell cultures of carrot, tobacco and Gardenia. Phytochemistry 30:3595-3597.

\section{ZDOLNOŚCI SYSTEMU ENZYMATYCZNEGO OWOCÓW I WARZYW DO HYDROLIZY WIĄZANIA ESTROWEGO}

\section{STRESZCZENIE}

Miąższ ziemniaka (Solanum tuberosum), topinambura (Helianthus tuberosum) i jabłka (Malus silvestris) hydrolizują w różnym stopniu, także całkowicie, wiązanie estrowe w octanach: fenylu, $\alpha$ - i $\beta$-naftylu, benzylu i cynamonylu. Hydroliza tego wiązania w estrach metylowych kwasów 4-acetoksy-3-metoksybenzoesowego i 2,5-diacetoksybenzoesowego jak i w propionianie testosteronu i 16,17-acetonidzie 21-acetoksy-6-fluoro-16 $\alpha$, $17 \beta$, 21-trihydroksy-4-pregnen-3,20-dionu przebiega selektywnie zarówno substratowo jak i wobec bioreagenta. Natomiast estry etylowe kwasu benzoesowego i cynamonowego wykazują widoczną odporność na hydrolizę.

SŁOWA KLUCZOWE: Malus silvestris, Solanum tuberosum, Helianthus tuberosus, hydroliza estrów, pochodne kwasu szikimowego, miąższ owoców, biotramsformacje. 